\title{
Zkušenosti studentů pedagogické fakulty s kyberšikanou
}

\author{
Experiences of the faculty of education students with cyberbullying
}

\author{
Jana Krátká, Radek Pospíšil
}

\begin{abstract}
Abstrakt: Kyberšikana se stává jedním ze závažných problémů současnosti. S rozvojem komunikačních systémů a zejména komunitních sítí je trendem propojovat svoji každodennost $\mathrm{s}$ virtuálním prostředím, $\mathrm{v}$ němž se stýkáme se stejnými lidmi jako v realitě, ale také s mnoha dalšími. Problematika však dosud není př́iliš reflektována pedagogickým výzkumem (srov. Kavalír, Rottová, 2009). Zajímá nás, jakým způsobem jsou studenti pedagogické fakulty nejčastěji konfrontováni $\mathrm{s}$ kyberšikanou. V př́spěvku se budeme zabývat analýzou dat zjištěných dotazníkovým šetřením realizovaným mezi studenty pedagogické fakulty. Budeme moci srovnávat informace získané od respondentů lišících se věkem, pohlavím a jejich obvyklým způsobem trávení volného času. Předpokládáme, že respondenti, kteří tráví více času ve virtuálním světě, budou také častějšími účastníky nebo svědky virtuálních forem šikany. Sekundárním výzkumným tématem bude zkušenost studentů učitelství s formami kyberšikany mezi žáky škol, s nimiž se setkávají během pedagogických praxí.
\end{abstract}

Klíčová slova: kyberšikana, studenti pedagogické fakulty, výzkum, dotazník

\begin{abstract}
Cyberbullying is one of the most serious problems of nowadays. With the communication systems and social networks progress, there is a trend to connect our everyday reality with a virtual environment, where we can meet same people like in the reality, but also many others. Although this theme isn't much reflected by the educational research yet (cp. Kavalír, Rottová, 2009). We are interested, how are the faculty of education students usually confronted with the cyberbullying. In this paper we will analyze information from questionnaire research realized among students of faculty of education. We will be able to compare information from respondents, who differ in age, gender and their usual leisure activities. We suppose, that respondents who spend more time in the virtual environment, will be more often participants or witnesses of the cyberbullying. Secondary research theme is the students' experience with the cyberbullying forms among primary and elementary school pupils during the students' eduactional practice preparation.
\end{abstract}

Keywords: cyberbullying, faculty of education students, research, questionnaire

\section{Kyberšikana}

Kyberšikana je konkrétním př́kladem zneužití moderních technologií. Jedním z jejích základních problémů je právě fakt, že se odehrává ve virtuálním prostoru (Vágnerová, 2009, s. 91). Pojem kyberšikana patrně poprvé použil kanadský profesor Bill Besley, který ji definoval slovy: „Kyberšikana zahrnuje využívání informačních a komunikačních technologií, které podporují úmyslné a opakující se neprátelské chování jednotlivce nebo skupiny, které vede k poškození ostatních“(Besley, 2005). 
Kyberšikana je dalším druhem šikany, kdy agresoři využívají jako nástroj $\mathrm{k}$ ubližování druhých lidí moderních technologií, jako je internet a mobilní telefony. Protože se jedná o poměrně novou problematiku, neexistuje přesná shoda ve vymezení jednotlivých proměnných, které s tímto fenoménem souvisí, jako je např́ílad doba, po kterou musí probíhat obtěžování, aby mohlo být označeno za kyberšikanu. Důsledkem těchto dohadů jsou rozdílné výsledky o rozšířenosti tohoto fenoménu.

Charakteristika kyberšikany podle Vanderbosch a Cleemput (2008):

- Agresor zraňuje obět' úmyslně s cílem ji poškodit.

- Obět' vnímá toto chování jako obtěžující, zraňující nebo jinak nepříjemné.

- Tento model chování se opakuje. V některých případech, kdy jde jen o umístění videa nebo fotografie na internet stačí jedna zkušenost.

- Vztah agresora a oběti je založen na nerovnováze, podobně jako je tomu u klasické formy šikany, kde převažuje rozdílný věk, fyzická síla, socioekonomickým postavením nebo v př́ípadě kyberšikany technologická převaha a anonymita.

Podle Vágnerové (2009) mezi důležitá specifika kyberšikany dále patř́i:

- Anonymita: Rozdílnost oproti běžné šikaně spočívá ve skutečnosti, že pachatel může zůstat anonymní a obět' se nikdy nemusí dozvědět, kdo ji šikanoval. Může jej znát, ale stejně si ji agresor mohl vybrat náhodou, třeba jen podle telefonního čísla, přezdívky. Anonymita pachatelům umožňuje agresi stupňovat a dovolit si to, co by si tváŕí v tvář nedovolili.

- Proměna agresora: Agresorem nemusí být fyzicky a sociálně silný jedinec, jako tomu bývá u běžné šikany, stačí, aby agresor zvládal základní znalosti o informačních technologiích.

- Proměna oběti: Také obětí se může stát kdokoli, bez ohledu na fyzickou a často i sociální zdatnosti.

- Před kyberšikanou není úniku: Při kyberšikaně může agresor obět' pronásledovat kdykoli a kdekoli, tj. i v „,bezpečí“ domova, kde porušuje její soukromí. Navíc tak může být zvyšován tlak vyvíjený klasickou šikanou.

- Absence fyzického násilí: Pokud se nejedná o doplnění klasické šikany, znesnadňuje absence fyzických poškození možnost odhalení kyberšikany školou či rodiči.

- Opakované zraňování: Při běžné formě šikany, si obět' nemusí každé slovo pamatovat, ale v případě e-mailů, textových zpráv, chatu a webových stránek si to, co jí agresoři napsali, čte neustále dokola, což má větší dopad na osobnost oběti. Zároveň uložený text nebo audiovizuální materiál může sloužit jako důkaz při vyšetřování kyberšikany.

- Nezávislost na místě a čase: Původce kyberšikany nemusí být fyzicky na stejném místě jako jeho obět'. Může jedince dostihnout prakticky v jakémkoli čase i na místech, kde se dříve cítil bezpečně, např́íklad doma.

\section{Formy kyberšikany}

Obvykle se jedná o úmyslné publikování nadávek, zesměšňujících informací, zveřejňování choulostivých nebo pozměněných fotografií a videí, posílání výhružných zpráv nebo urážek a 
další činnosti, které mají především poškodit, popřípadě zesměšnit obět' před okolím. Kyberšikana posiluje projevy klasické šikany. Jednou z forem kyberšikany je také vydávání se za obět' samotnou. Př́klady forem kyberšikany:

- Kyberšikana pomocí mobilního telefonu zahrnující především zneužívání nahrávek, fotografíi apod.

- Neustálé volání v podobě vydírání, zastrašující hovory či jiné nemravné obtěžování po telefonu, neustálé prozvánění atd.

- SMS a MMS výhružné a nenávistné zprávy jsou jednou z nejjednodušších forem vyjádření nenávisti druhé osobě.

- Chatovací místnosti patří mezi nejrozšířenější prostředky kyberšikany ve virtuálním světě, nicméně jen s nepatrnými negativními důsledky pro potenciální obět', protože umožňují komunikaci v reálném čase mezi dvěma nebo více uživateli.

- Zneužití obsahu internetových stránek je již výrazně zaměřenou formou kyberšikany. Útočník vytvoří internetovou stránku o své oběti, kde bude zveřejňovat důvěrné informace o její osobě s cílem ponížit ji a zesměšnit.

- Hlasovací ankety, které např. mají rozhodnout o nejhloupější nebo nejtlustější osobě ve škole.

- Zneužití aplikace instant messengerů (např. ICQ, QIP, Skype, AOL, MSN), kdy se např. agresor vydává za obět'.

- Zneužití e-mailu především pro posílání zpráv výhružných, ponižujících, se sexuálním podtextem, rozesílání upravených fotografií, ponižujících videí apod.

- Zneužití informací na sociálních sítích, fotografií, videí či falešné zakládání profilů, pomlouvání a psaní ponižujících komentářù.

\section{Metodologie výzkumného šetření}

Naším výzkumným cílem bylo zjistit, jakým způsobem jsou studenti pedagogické fakulty nejčastěji konfrontováni s kyberšikanou, at' již osobně nebo v průběhu pedagogických praxí. Pro tyto potřeby byl vytvořen krátký dotazník (obsahující 12 uzavřených a otevřených otázek), který jsme distribuovali mezi studenty Pedagogické fakulty Masarykovy univerzity. Nezajímali jsme se o demografické položky, ale pouze o ročník a typ studia respondenta.

Dotazník byl konstruován tak, aby bylo možné srovnávat informace získané od respondentů lišících se věkem, pohlavím a jejich obvyklým způsobem trávení volného času. V analýze dat se však nezabýváme $\mathrm{v}$ českých sociálních vědách tradiční a přeceňovanou statistickou významností hypotéz nikoli proto, že by výše specifikovaný vzorek nebyl dostatečně zajímavý, ale není podle objektivních statistických hledisek reprezentativní, ačkoli bychom i zde mohli použít statistické metody analýzy dat (srov. Soukup \& Rabušic, 2007). Získaná data považujeme za spíše orientační pro prvotní náhled na problematiku, která by si v budoucnu vyžádala mnohem zásadnější sledování. $Z$ toho důvodu prezentujeme pouze charakteristiku získaných poznatků, nikoli statisticky ověřované výzkumné hypotézy a jejich zobecňování.

Celý výzkumný soubor tvořilo 452 respondenti̊, z toho množství bylo 402 žen a 50 mužů. $\mathrm{Z}$ pohledu věkové skupiny bylo zastoupeno 317 studentů ve věkové skupině 20-25 let, 97 
studentů ve věku 26 a více let a 38 studentů bylo mladších 20 let. Podle formy studia, je 115 studentů kombinovaného studia a 337 studentů prezenčních.

\section{Výsledky výzkumného šetření}

\subsection{Setkání studentů pedagogické fakulty s kyberšikanou}

Předpokládali jsme, že respondenti, kteří tráví více času ve virtuálním světě, budou také častějšími účastníky nebo svědky virtuálních forem šikany, bez ohledu na věk a pohlaví. Dotazovaní respondenti uvedli, že denně průměrně stráví ve virtuálním prostředí, které je interaktivní s ostatními lidmi (komunitní sítě, chat, diskusní fóra, on-line hry apod.) 1-3 hodiny, přičemž u mladších studentů a současně studentů prezenčních nebyl počet takto strávených hodin výrazně vyšší, než u starších, kombinovaných studentů. Někteří respondenti uvedli mnohem vyšší počet hodin, z čehož však usuzujeme o spuštěné aplikaci tzv. na pozadí, ve vedlejší záložce apod., která je během dne jen komunikační možností, nikoli komplexní náplní času jedince. Komunitní sítě typu Facebook, Twitter apod. využívá 393 respondentů, tj. $87 \%$. Výše uvedený dílčí výzkumný předpoklad o tom, že respondenti, kteří tráví více času ve virtuálním světě, budou také častějšími účastníky nebo svědky virtuálních forem šikany se nepotvrdil, nebot' 448 (99 \%) studentů uvedlo, že se s kyberšikanou osobně na komunitních sítích nesetkávají. Můžeme tedy spíše usuzovat na fakt, že v případě dospělých osob diskutovaná problematika není tolik aktuální.

\subsection{Pojem kyberšikana v predstavě studenti̊ pedagogické fakulty}

Naše výzkumné šetření zahrnulo také otázku, co studenti rozumějí pod pojmem kyberšikana. Při analýze stručných volných odpovědí jsme se setkali nejčastěji s vyjádřeními, která zahrnovala pojmy související s kyberšikanou: internet, mobilní telefon, týrání, zneuživání, ponižování, zesměšňování. Z těchto odpovědí můžeme usuzovat, že studenti pedagogické fakulty mají relativně správnou představu, co termín kyberšikana zahrnuje, a že se již s pojmem setkali.

\subsection{Kyberšikana mezi žáky na pedagogických praxích}

Sekundárním výzkumným tématem byla zkušenost studentů učitelství s formami kyberšikany mezi žáky škol, s nimiž se setkávají během pedagogických praxí. Za tímto účelem jsme se respondentů dotazovali na charakteristiky jejich pedagogických praxí: 177 respondentů absolvovalo praxi na plně organizované škole, 114 respondentů na městské škole, 109 respondentů na vesnické škol a 52 na škole málotř́ídní. $Z$ toho praktikovalo $81 \%$ respondentů v 6.-9. ročníku a $19 \%$ v 1.-5. ročníku. Zajímali jsme se o to, s jakou formou kyberšikany se podle studentů nejčastěji setkávají žáci na základní škole. Respondenti měli v připadě této otázky vybrat jednu nebo více možností, které uvádíme v pořadí, jak často byly studenty uváděny:

1. rozesílání urážlivých sms (435),

2. zveřejňování urážlivé fotografie (313),

3. zveřejňování dehonestujících videozáznamů (306),

4. zneužití osobních dat v e-mailu nebo na komunitní síti (257),

5. obdržení urážlivých e-mailů (178), 
6. rozesílání urážlivých e-mailu z adresy oběti (114).

Z těchto údajů vyplývá, že dotazovaní studenti pedagogické fakulty předpokládají, že problematika kyberšikany je v prostředí základní školy velice rozšířená a v tomto smyslu, očekávají setkání s ní. Dále jsme se studentů dotazovali, zda se během svých pedagogických praxí setkali s kyberšikanou mezi žáky a v jaké formě. Na otázku v podobě volné odpovědi odpovědělo kladně jen 11 studentů z celkového počtu 452 respondentů. Tito obvykle uvedli, že v průběhu své praxe na škole slyšeli o tom, že mezi studenty došlo ke zneužití mobilního telefonu, anebo zveřejnění urážlivého videa, fotografie. Z rozporu mezi velkým očekáváním studentů, co se týče konfrontování žáků s kyberšikanou na základní škole a s jejich reálným setkáním s problematikou během praxí však nemůžeme jednoznačně usuzovat na skutečnost, že se kyberšikana ve větší míře nevyskytuje ani mezi dětmi.

\section{Závěr}

Námi zkoumané téma lze označit $\mathrm{v}$ současné době za velmi aktuální a potřebné. Zjištěná data považujeme za úvodní informaci a impuls k dalšímu zkoumání problému. Lze očekávat zapojení menšího počtu studentů a žáků a přechod ke smíšenému designu výzkumu se zaměřením na porozumění kyberšikaně a jejímu výskytu.

\section{Literatura}

Besley, B. Cyberbullying: An emerging threat to the ,always on“ generation. In www.cyberbullying.ca Dostupné z http://www.cyberbullying.ca/pdf/Cyberbullying_Article_by_Bill_Belsey.pdf

Kavalír, A., \& Rottová, N. et al. (2009). Kyberšikana a jeji prevence - přiručka pro učitele. Plzeň: Dragon Press.

Soukup, P., \& Rabušic, L. (2007). Několik poznámek k jedné obsesi českých sociálních věd, statistické významnosti. In Sociologický časopis/Czech Sociological Review, 43(2), 379-395. Praha: Sociologický ústav AV ČR.

Vágnerová, K. et al. (2009). Minimalizace šikany. Praha: Portál.

Vandebosch, H., \& Cleemput, V. K. (2008). Defining cyberbullying: A qualitative research into the percepcions of youngsters. CyberPsychology \& Behavior, 11(4), 499-503.

\section{Kontakt}

Mgr. Radek Pospíšil

Mgr. Jana Krátká, Ph.D.

Masarykova univerzita

Pedagogická fakulta, Katedra pedagogiky

Poŕíćí 31, 60300 Brno

e-mail: pospisil@ped.muni.cz

kratka@ped.muni.cz

\section{Bibliografické údaje}

Krátká, J., \& Pospíšil, R. (2011). Zkušenosti studentů pedagogické fakulty s kyberšikanou. In T. Janík, P. Knecht, \& S. Šebestová (Eds.), Smišený design v pedagogickém výzkumu: Sborník přispěvků z 19. výročni konference České asociace pedagogického výzkumu (s. 189-193). Brno: Masarykova univerzita.

Dostupné z: http://www.ped.muni.cz/capv2011/sbornikprispevku/kratkapospisil.pdf doi: 10.5817/PdF.P210-CAPV-2012-32 